\title{
O I Festival Internacional de Cinema do Brasil (1954)
}

\section{Rafael Morato Zanatto}

Escola de Comunicação e Artes, Universidade de São Paulo (ECA/ USP - FAPESP) rafael_zanatto@hotmail.com

https://orcid.org/0000-0001-6623-4668

RESUM O O I Festival Internacional de Cinema do Brasil (1954) foi a tentativa brasileira de participar do circuito internacional dos festivais de cinema que ganhou fôlego na Europa após a II Guerra Mundial. Concebido como parte das comemorações do IV Centenário da cidade de São Paulo, o festival baseou-se no modelo dos festivais de Cannes, Veneza, Bruxelas (1947) e Knokke Le Zoute (1949). Aprofundando as lições dos festivais europeus, o brasileiro harmonizou em sua programação mostras de enfoque comercial e retrospectivas culturais, mas com o fracasso das expectativas comerciais locais e com o sucesso das programações culturais, cristalizou-se a percepção em parcela da crítica e da crônica que arte e mercado foram dispostas em polos opostos, no qual as mostras comerciais haviam sido preteridas em relação às retrospectivas e atividades de cunho cultural. Analisando historicamente o caso do festival, veremos como seu fracasso comercial e sua única realização resultam diretamente da crise econômica que se abateu sobre o país e sobre a indústria cinematográfica local, demonstrando que oposição entre arte e comércio reflete, na realidade, disputas entre as cinematografias estadunidense e europeia. Veremos ainda que a vitalidade das programações culturais será fundamental para a boa repercussão que o evento alcançará na crítica estrangeira, evitando o fracasso completo da iniciativa.

PALAVRAS-CHAVE I Festival Internacional de Cinema do Brasil; cultura cinematográfica; festivais de cinema; Paulo Emílio; arte e mercado; filmotecas.

Não é um Festival da técnica, é um Festival do espírito!

Henri Langlois (Koval 1954, 306)

\section{Introdução}

Fenômeno social complexo, específico em relação ao contexto em que floresce e global pelo diálogo que suscita entre paradigmas produtivos e fisionomias nacionais, os festivais de cinema se consolidaram como tema de pesquisa. Nos últimos anos, os trabalhos de Thomas Elsaesser (2005) e 
Marijke de Valck (2007) e coletâneas (De Valck, Kredell e Loist 2016) investigaram os festivais de cinema, traçando sua etnografia, geografia, história e arqueologia a partir de estudos de caso. ${ }^{1}$

Amparando-nos nessas perspectivas teórico-metodológicas, investigaremos o caso do I Festival Internacional de Cinema do Brasil, realizado na cidade de São Paulo entre 12 e 26 de fevereiro de 1954. Concebido no âmbito das comemorações do IV Centenário da cidade, o festival integra a efervescência cultural que São Paulo experimentou com o fim da II Guerra Mundial e, localmente, do Estado Novo (1937-1945). A partir de 1946, os paulistanos presenciaram a fundação de muitas instituições voltadas à difusão e expansão da cultura urbana e burguesa. Floresceram dois museus de arte, uma grande e moderna casa de espetáculos e uma companhia teatral de alto nível. Multiplicaram-se os concertos, escolas de arte, conferências, seminários, exposições, revistas de divulgação artística e cultural (Galvão 1981).

Fundado para impulsionar a formação de um mercado de arte no Brasil, o Museu de Arte Moderna - MAM-SP (1948) absorveu a intelectualidade paulistana reunida no Segundo Clube de Cinema de São Paulo (1946) para formar sua Filmoteca (1949), dada a importância do cinema para a formação cultural e artística do público em geral. No mesmo ano, a fundação da Companhia Cinematográfica Vera Cruz (1949) inicia a produção industrial de filmes para fazer frente à presença massiva do cinema estadunidense no mercado local e para exportá-los. Paralelamente, a Filmoteca e a Vera Cruz refletem o novo momento local, cultural e comercial iniciado no domínio das artes plásticas e que se aprofunda na realização da I Bienal de Artes Plásticas (1951) do MAM-SP.

O fortalecimento local e internacional da filmoteca (Correia Jr. 2010), os primeiros congressos de cinema (paulista e nacional) (Souza 2005) e o êxito dos primeiros filmes da Vera Cruz reforçaram a percepção de que, após as artes plásticas, era a vez do cinema. Nesse contexto, o I Festival Internacional de Cinema do Brasil foi concebido para favorecer o estabelecimento de laços comerciais e culturais com os países europeus, latino-americanos e os EUA. No Brasil, a parte cultural do festival foi analisada nos livros de José Inácio de Melo Souza (2002), Adilson Mendes 1 Veja-se também a série de livros 'Framing Film Festivals', editada por Marijke de Valck e Tamara Falicov na
Palgrave Macmillan. 
(2013) e Fausto Correia Jr. (2010) e nas teses de Carlos Roberto de Souza (2009) e Fausto Correia Jr. (2012) no âmbito das contribuições de Paulo Emílio Sales Gomes e da Cinemateca Brasileira.

Em diálogo com os trabalhos predecessores, tomaremos o festival como questão historiográfica, experimentando as hipóteses seguintes: (1) o festival foi idealizado para contemplar aspectos artísticos e comerciais do cinema brasileiro; (2) a relação entre arte e mercado está presente na programação; (3) a oposição entre arte e mercado, que se manifesta na crítica e na crônica, é um falso problema que desfoca a verdadeira tensão provocada pelo evento: a disputa cultural e comercial entre os cinemas europeu e estadunidense; (4) o fato de ter sido realizado uma única vez decorre da não continuidade do fomento governamental, legitimado à época pela realização do IV Centenário de São Paulo; (5) seu destino se liga mais à crise que se abateu sobre a então recente indústria cinematográfica local do que propriamente uma oposição proposital entre arte e mercado idealizada pela organização, como se aventou à época. A partir dessas hipóteses, veremos como o festival é um momento decisivo da história do cinema no Brasil, da ruína comercial e da fortuna da cultura cinematográfica.

\section{A concepção do festival}

Na concepção do festival, cultura e comércio foram harmonizadas para contribuir com desenvolvimento do cinema brasileiro em sua diversidade de problemas técnicos, econômicos e artísticos, seguindo o modelo dos festivais de cinema europeus. De todos os envolvidos na concepção do festival,2 Paulo Emílio foi o nome mais importante na adequação das lições estrangeiras ao contexto brasileiro, como sustentam as pesquisas brasileiras supracitadas.

Entre maio de 1946 e janeiro de 1954, Paulo Emílio residiu em Paris, onde frequentou o IDHEC (Institut des Hautes Études Cinématographiques), as

\footnotetext{
${ }^{2}$ A secretaria-executiva do festival foi presidida pelo advogado José Gonçalves Andrade Figueira. As mostras culturais foram conduzidas por personalidades como Francisco Luís de Almeida Salles, primeiro presidente da Filmoteca do Museu de Arte Moderna (MAM-SP), dirigido por Francisco Matarazzo Sobrinho; B.J. Duarte, cineasta e crítico; Lourival Gomes Machado, professor da Universidade de São Paulo e crítico de arte; Caio Scheiby e Rudá de Andrade, pesquisadores e conservadores-adjuntos da Filmoteca, além de Paulo Emílio, que em 1954 assume o posto de conservador-chefe da instituição.
} 
aulas do grupo de Filmologia na Sorbonne e cursos e mostras na Cinémathèque Française. Nesse período, participou como festivalier ou como membro do júri em festivais de cinema como os de Cannes, Veneza, Bruxelas (1947) e Knokke Le Zoute (1949); atuou na FIAF-Fédération Internationale des Archives du Film sob o amparo das credenciais de representante da Filmoteca do MAM-SP e, em 1951, ocupou a vice-presidência da federação (Souza 2002). Após oito anos participando dos movimentos de cultura cinematográfica na Europa, berço dos festivais de cinema (De Valck 2007), Paulo Emílio retorna ao hemisfério Sul empenhado em adaptar as lições aprendidas ao contexto brasileiro, sendo o festival sua primeira oportunidade.

O evento seguiu o espírito de colaboração internacional e o método de escolha dos filmes da Seleção Oficial do festival de Cannes, no qual cada país indicava seus representantes (Ostrowska 2016, 19) - modelo mais focado nas possibilidades comerciais dos filmes contemporâneos. Já a parte artística e cultural, desdobrada da II Bienal de Artes Plásticas (MAM-SP), evocou o modelo do festival de Veneza (De Valck 2016, 102). Mas o paradigma decisivo do festival brasileiro foi o experimentado pelos festivais belgas: o Festival Mondial de Beaux-Arts de Bruxelles (1947) e o Festival de Knokke Le Zoute (Gomes 1954).

Ao contrário de Cannes e Veneza, a importância desses festivais não residiu na qualidade de sua competição principal, mas na diversidade das mostras, segmentadas por categorias, como a dos filmes experimentais, poéticos, de valor histórico, entre outros. Ao lado das mostras, os belgas avançaram realizando em paralelo exposições de artes plásticas, apresentações teatrais e musicais. Ao mesmo tempo, exposições de documentos, revistas, fotografias, dispositivos ópticos, equipamentos e objetos que integram a cultura material cinematográfica reforçavam o caráter espetacular e os propósitos pedagógicos do festival, voltado à formação cultural do público. Neles, destacou-se a realização de discussões sobre o estabelecimento de políticas de preservação e difusão cinematográficas (Correia 2012), propostas de pesquisa, estratégias de formação cultural e cineclubismo, além de aspectos comerciais, como acordos de coprodução e distribuição.

Partindo da experiência dos festivais europeus, o festival brasileiro manifestou sua face comercial na Seleção Oficial de filmes inéditos no Brasil, 
selecionados pelas comissões dos 21 países inscritos. ${ }^{3}$ As mesmas comissões ficaram responsáveis pela escolha dos filmes das Jornadas Nacionais, uma mostra das produções mais expressivas dessas cinematografias lançadas entre 1952 e 1953, algumas delas ainda inéditas no país anfitrião. Para coordenar os trabalhos da Seleção e das Jornadas, a organização do festival contratou Jean Sermaize, então técnico do Festival de Cannes, como Secretário Técnico Adjunto, desse modo enfatizando a importância do modelo francês para a parte comercial do festival brasileiro.

$\mathrm{Na}$ parte cultural, Paulo Emílio concebeu duas retrospectivas históricas estrangeiras: a dos 'Grandes Momentos do Cinema' e a 'Retrospectiva Erich von Stroheim' (Figura 1). Já Caio Scheiby e B. J. Duarte apresentaram a história nacional na II Retrospectiva do Cinema Brasileiro. Ainda no campo das programações culturais, devemos listar o Festival de Cinema Infantil, organizado por Sonika Bô, diretora do Club Cendrillon (Paris), e o Festival de Cinema Científico-Educativo, coordenado por B.J. Duarte com o apoio do Instituto Nacional de Cinema Educativo (INCE) e de Jean Painlevé, presidente da Associação Internacional do Cinema Científico - instituição que disponibilizou seu acervo. Realizaram-se ainda exposições, entrevistas coletivas, reuniões e conferências de grandes nomes da cultura cinematográfica, como André Bazin, Henri Langlois, Gianni Comencini e Ernest Lindgren. ${ }^{4}$

Analisando a programação do festival, nota-se como a parte cultural foi muito superior aos programas mais comerciais, trazendo nomes de relevo para a história do cinema, como Abel Gance e Erich von Stroheim, apresentando cinco programas sobre a história do cinema nacional e estrangeiro, e congregando os principais expoentes da cultura cinematográfica europeia. No caso da Seleção Oficial, não foram os principais astros e estrelas, nem os melhores filmes do período que vieram a São Paulo, abalando as altas expectativas daqueles que esperavam a

\footnotetext{
${ }^{3}$ Segundo o periódico Última Hora, de 18 de Fevereiro de 1954, foram eles: Argentina, Estados Unidos, Uruguai, Venezuela, Peru, Canadá, Alemanha, Áustria, Espanha, França, Inglaterra, Itália, Iugoslávia, Japão, Suécia, Suíça, Holanda, México, Portugal, Brasil e Chile (o único país inscrito que não exibiu filmes).

${ }^{4}$ A nota Conferências, publicada no periódico Última Hora (10 fev. 1954), reporta as seguintes participações: Gianni Comencini (Cineteca Italiana): “Tendência do Cinema Italiano” (14/02); André Bazin (Cahiers du Cinéma): "Robert Bresson ou a Tirania do Estilo", com exibição de As Damas do Bosque de Bolonha (16/02), e "Defesa do Cinema Impuro" (21/02); Henry Langlois (Cinémathèque Française): "O caso Prévert" ou "O avesso do cinema francês", com projeção de Adieu Leonard (17/02), e "A obra francesa de Alberto Cavalcanti”, com a exibição de Nada Além das Horas (23/02). Ernest Lindgren (British Film Institute): "Um diretor inglês: Anthony Asquith" (19/02) e "A carreira de Cavalcanti no filme documentário britânico" (25/02).
} 
presença dos maiores nomes do cinema estadunidense, assim como dos melhores filmes dos países inscritos na Seleção Oficial.

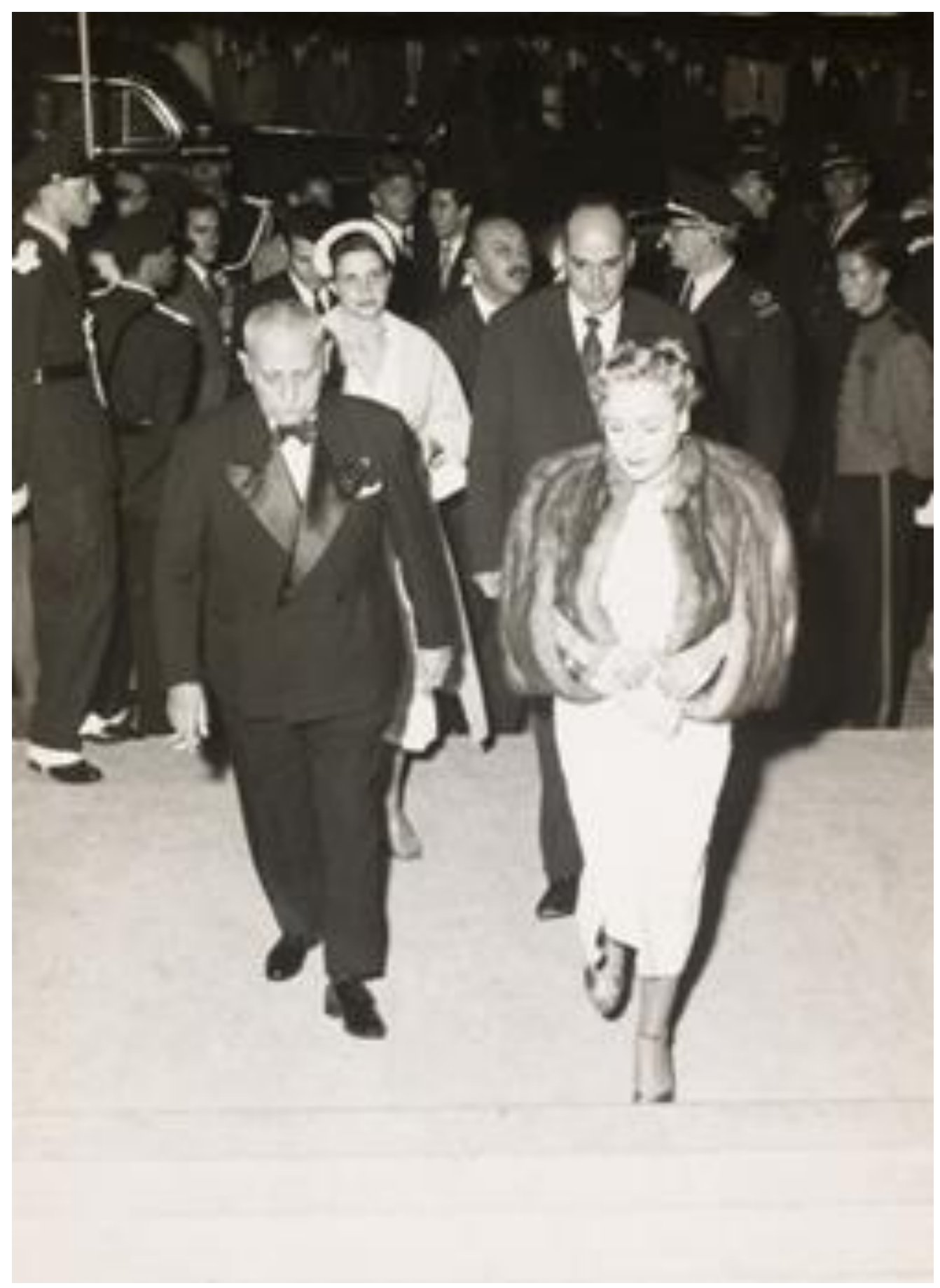

Figura 1: Paulo Emílio e sua esposa Sônia Borges acompanham Erich von Stroheim e Denise Vernac na estreia da 'Retrospectiva Erich von Stroheim', no Cine Marrocos. | (c) Cinemateca Brasileira. 


\section{Nem vencedores nem prêmios: a Seleção Oficial}

Baseada na competição dos festivais de Cannes e Veneza, mas sem conferir prêmios, a Seleção Oficial de São Paulo exibiu 71 filmes de curta-metragem e 32 de longa-metragem no Cine Marrocos, entre os dias 12 e 26 de fevereiro. No dia 13 de fevereiro, o jornal $A$ Tribuna noticiou: "Solenemente inaugurado o Festival de Cinema do Brasil". Delegações nacionais, autoridades brasileiras e o público assistiram ao curta italiano Vitrais de Arte, ao estadunidense $O$ Coração Revelador, baseado na obra de Edgar Allan Poe, e ao canadense Begone Dull Care, de Norman Mac Laren, sobre a técnica de gravação artística do som em celuloide. Após os curtas, foi exibido o longa Música e Lágrimas, programado para agradar a um público mais familiarizado com o cinema estadunidense, mas que se provou uma produção "medíocre”, "que se arrastou durante duas horas, chegando ao fim com um cinema quase vazio".

No conjunto da mostra, destacaram-se na categoria de curta-metragem filmes como o documentário português Hulha Branca, apreciado pelas imagens e criticado pela narração, e Quick, o Esquilo, elogiado por humanizar a "vida íntima" do animalzinho, conforme se pode ler na edição de $O$ Estado, de 16 fevereiro de 1954. Na categoria, o Brasil foi representado pelos curtas Fortunas Escondidas e Entre o Mar e o Tendal, documentário em cores sobre a beleza das paisagens baianas, suas praias, e "a humanidade dos seus humildes, místicos e fortes pescadores" (Diário 10 fev. 1954). No canadense The Romance of Transportation in Canada, também se destacou dos demais títulos, mas, ao final do festival, consolidou-se a percepção de que o melhor curta exibido foi o holandês Houen Zo!, de Herman Van Der Horst. O cinema uruguaio foi representado por "duas obras com complicados acertos e alguns outros triviais descontroles": Turay, Enigma de las Llanuras e Puplia al Viento, ambas de Enrico Gras (O Estado 27 fev. 1954).

Devemos salientar que a presença de filmes sul americanos no mercado exibidor brasileiro não era uma realidade, o que acentua a importância diplomática da presença desses filmes. Apesar disso, nenhuma parceria produtiva foi firmada entre produtores brasileiros e sul-americanos, em parte, pelo fato de que os produtores brasileiros se preocuparam mais em buscar parcerias com produtoras estadunidenses e europeias do que estreitar laços com os países vizinhos. No contexto latino-americano, devemos ainda citar a presença do cinema mexicano, representado por filmes como A Louca, de Miguel Zacarías. Mas ao contrário do que se passou com o cinema venezuelano e uruguaio, o mexicano foi duramente criticado 
por Novais Teixeira, decepcionado com a demonstração clara do descaso desse país com o festival (O Estado 16 fev. 1954). Os representantes do Brasil, Chamas no Cafezal e $\mathrm{Na}$ Senda do Crime foram julgados pífios e "falsos", enquanto que o "artesanal" O Gigante de Pedra, do estreante Walter Hugo Khouri, foi tomado como a grande revelação (Visão 14 mar. 1954, 3334). No balanço do Suplemento Especial Cinematográfico do jornal O Estado de S. Paulo, foram considerados os melhores filmes o sueco Noites de Circo e o estadunidense $A$ Princesa e o Plebeu. Outros títulos, como o alemão Coração que Dança e os franceses Julieta e $O$ Curandeiro foram apenas dignos de destaque (O Estado 27 fev. 1954, 33).

Sobre a seleção, Claude Lefort interpretou a programação à luz de uma "ironia secreta" presente em sua concepção, cuja finalidade parecia ser a de inquietar os espectadores rivalizando "os músculos do [Július] César ianque" às "covinhas de Julieta" (Lefort 1954, 15). Com o comentário, Lefort evidencia a presença da tensão comercial e cultural entre a indústria estadunidense e as produtoras europeias, temas de que dividiam a crítica de cinema do período, mas que como vimos, não participaram da escolha dos filmes da seleção. Comentando os filmes exibidos, André Bazin não elegeu um vencedor, mas indicou aos leitores da Cahiers du Cinéma os sete melhores filmes: os italianos Pão, Amor e Fantasia e O Sol nos Olhos; e os franceses Julieta, $O$ Curandeiro, $O$ Amor de uma Mulher e Amor de Outono. Condenados, de Manuel Mur Oti, foi apontado como a "única surpresa agradável" da Seleção Oficial (Bazin 1954).

Ao julgar a mostra, parte da imprensa brasileira considerou que as melhores produções dos países participantes haviam sido reservadas aos festivais de Cannes e Veneza, exceto a bastante apreciada categoria de curta-metragem. Dentre os motivos listados, estava a falta de prestígio do festival brasileiro e a ausência de premiações. Negligenciando essa parte importante da legitimação cultural e do capital simbólico que os realizadores buscam agregar aos seus filmes, tendo em vista sua distribuição internacional (De Valck 2016, 102), o festival brasileiro foi interpretado à época como pouco atrativo pelas produtoras estrangeiras.

Em seu balanço, Novais Teixeira ponderou que, se existiam festivais fracos, médios e ruins, a Seleção Oficial havia sido mediana (1954, 44). Francis Koval afirmou que nenhuma obra de arte ou filme que merecesse grande atenção da imprensa mundial havia sido exibido, ressaltando que muito poucos filmes dessa natureza eram produzidos, e não era surpresa que filmes dessa qualidade não seriam apresentados em um festival tão distante, realizado pela primeira vez e sem prêmios, mas sim reservados 
aos festivais de Cannes e Veneza (Koval 1954, 306). Dos críticos estrangeiros, Bazin foi o mais categórico: "São filmes medíocres, que não foram escolhidos com seriedade" (Folha da Tarde 17 fev. 1954). Segundo ele, "Apenas a França e a Itália haviam jogado lealmente o jogo e tratado São Paulo em igualdade com Cannes e Veneza", enquanto Estados Unidos, Inglaterra e Áustria haviam inscrito filmes já apresentados nos festivais europeus (Bazin 1954, 27).

Se por um lado, o comentário de Bazin explica a ausência de filmes estadunidenses em sua lista, por outro, não se pode legitimá-lo inteiramente, pois nenhum filme francês ou italiano de longa-metragem que passou no festival foi premiado nos festivais de Cannes e Veneza em 1954. 0 dado reforça nossa percepção de que os melhores filmes do ano não foram inscritos no festival brasileiro, preterido pela falta de prêmios, prestígio e posição periférica no âmbito dos festivais, frustrando as altas expectativas comerciais das produtoras locais. Já na parte cultural, as mostras 'Grandes Momentos do Cinema' e 'Retrospectiva Erich von Stroheim' não apenas confirmaram e superaram as expectativas, como foram tomadas como um acontecimento cultural sem precedentes.

\section{'Grandes Momentos do Cinema'}

A mostra 'Grandes Momentos do Cinema', de recorte panorâmico, contou com quinze programas, mantendo a frequência de duas sessões diárias no Museu de Arte Moderna (MAM-SP). Filmes dos EUA, França, Suécia, Itália, Rússia e Alemanha ofereceram um panorama da história do cinema mundial, possível apenas pela colaboração dos arquivos de filme da FIAF5 por intermédio de Paulo Emílio. As obras exibidas no programa e algumas outras foram, na ocasião, incorporadas ao acervo da Filmoteca. Correia Jr. tem razão quando afirma que essa aquisição representou um ganho sem precedentes para as atividades político-pedagógicas da Filmoteca do MAM, entidade que a partir de 1956 passou a se chamar Cinemateca Brasileira (Correia 2010).

\footnotetext{
${ }^{5}$ Que, então, incluía as seguintes instituições: Cinémathèque Française, Cinémathèque de Lausanne, George Eastmann House, Film Library (MoMA-NY), Library of Congress, Academy of Motion Picture Arts and Sciences, Cinémathèque Royale de Belgique, British Film Institute, Sovexportfilm, Cineteca Nazionale de Roma, Cineteca Italiana, Tekniska Museet (Svenska Filminstitutet), Institut Cinematographique Tchecoslovaque, Nederlands Filmmuseum e Cinemateca Portuguesa (Gomes 27 fev. 1954, 32).
} 
Na abertura, Paulo Emílio apresentou ao público a programação geral das retrospectivas e comentou filmes de Georges Méliès ${ }^{6}$ e de $\operatorname{Max} \operatorname{Linder}^{7}(O$ Estado 13 fev. 1954). Além dos clássicos do primeiro cinema francês, a mostra apresentou momentos decisivos da formação das escolas cinematográficas estadunidense, italiana, alemã, sueca, soviética e francesa até 1930, embora sua ambição inicial fosse ilustrar a história do cinema até o início da II Guerra Mundial (1939). ${ }^{8}$ Apesar das lacunas, a mostra foi a primeira retrospectiva panorâmica da história do cinema mundial no âmbito dos festivais de cinema, distinguindo-se do recorte histórico nacional das retrospectivas de Veneza (Manchete 10 Abr. 1954) e do temático experimentado nos festivais belgas (Souza 2002).

$\mathrm{Na}$ mostra, dois cineastas foram homenageados pelo conjunto da obra: Alberto Cavalcanti e Abel Gance. Para homenagear Gance, o festival tentou exibir Napoleão no tríptico, tal como o cineasta havia realizado em 1927. Bazin (1954) relatou que a exibição não ocorreu, mas o correspondente inglês Francis Koval afirmou que os problemas técnicos foram resolvidos às 2 da manhã, quando o filme foi exibido para 2000 mil pessoas $(1954,307)$. Nessa história, a versão mais fiável talvez seja a de Rudá de Andrade, projecionista da sessão, que afirmou que a exibição em polivisão nas telas laterais do tríptico não funcionou corretamente, efetivando-se apenas a da tela central (2004), o que não impediu a fervorosa aclamação do público ao filme para a emoção de Abel Gance, presente na sessão.

Já a homenagem a Alberto Cavalcanti possuiu um sentido mais profundo, como Bazin interpretou a exibição de Nada Além das Horas. Até então, o crítico não conhecia a obra francesa de Cavalcanti, a ele apresentada pela conferência de Langlois ministrada após a sessão. Seu interesse se desdobrou em uma visita à casa de Cavalcanti, onde conheceu sua obra, dotada de um "refinamento atemporal, prenhe de um humanismo moderno e ao mesmo tempo, anacrônico" (Bazin 1954, 28). Sua coleção, composta de fotogramas, películas e outros objetos eram "tesouros escondidos em uma

\footnotetext{
${ }^{6}$ O Maravilhoso Leque Vivo e As Quatrocentas Farsas do Diabo.

${ }^{7}$ Max se trompe d'étage, Max veut Grandir e Max Pratique tous les Sports.

${ }^{8} \mathrm{O}$ programa incluiu os seguintes filmes: animações de Émile Cohl; A Viagem Imaginária; A idade do Ouro; O Cão Andaluz (França); Cabiria (Itália); O Nascimento de uma Nação, $O$ Vento; Aurora (EUA); $A$ Carruagem Fantasma; $O$ Tesouro de Arne (Suécia); O Gabinete do Dr. Caligari (fragmentos); Nosferatu; Sombras: Uma Alucinação Noturna; o Gabinete das Figuras de Cera; Berlim: Sinfonia de uma Grande Cidade (Alemanha); O Encouraçado Potemkin; Outubro; Viva México; A Mãe: A Terra; O Homem com a Câmera (URSS). Os filmes silenciosos sem trilha foram musicados pelo maestro italiano Pierluigi Sampietro (Diário 07 fev. 1954).
} 
extraordinária caverna da cultura" cinematográfica, "lugar de um refinamento inacreditável", "fora do tempo e da geografia" (Bazin 1954, 28).

Encontros como esse foram relevantes para estreitar os laços entre latino-americanos e europeus envolvidos nas questões históricas e culturais do cinema, com o início das discussões sobre a organização de uma secção latino-americana da FIAF. Langlois contatou representantes de instituições latino-americanas, como a Cinemateca Uruguaia, aos quais apresentou um projeto pronto para a criação da secção (Correia 2012, 45). A iniciativa visava desenvolver pesquisas históricas de cinema no continente e selar a colaboração internacional entre as instituições filiadas à federação. Nesse âmbito, a mostra 'Grandes Momentos' era uma demonstração objetiva da importância da solidariedade e da ativação de um plano de trabalho mundial para as cinematecas. Como complemento da mostra, foi montada uma exposição com painéis enviados pela UNESCO para ilustrar a história do cinema mundial, dos primeiros dispositivos ópticos ao cinema contemporâneo (Diário 14 fev. 1954).

\section{'Retrospectiva Erich von Stroheim'}

Assim como 'Grandes Momentos', a 'Retrospectiva Erich von Stroheim', de recorte biográfico, foi acompanhada de uma exposição completa, composta de extratos de filmes, imagens e manuscritos originais apresentados ao público pela primeira vez no mundo "devido à gentileza do senhor Stroheim", que "abriu os seus arquivos e suas coleções de fotografias" (Gomes 1954, 333). Assim como a exposição, a própria retrospectiva nasceu do encontro entre Paulo Emílio e Stroheim na Cinémathèque Française. 


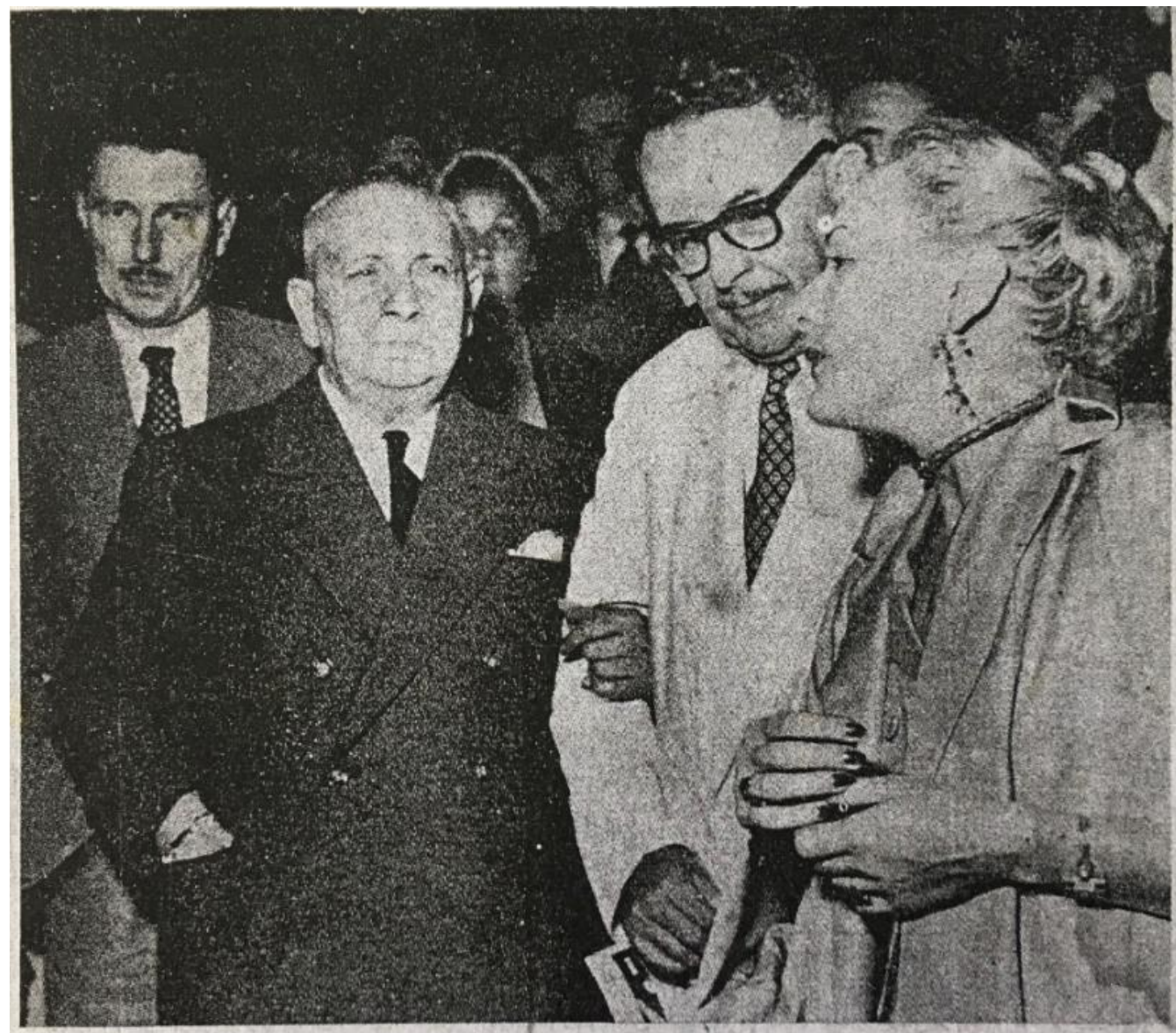

PRIMEIRO ENCONTRO dos diretores Von Stroheim e Cavalcanti, numa das sessőes dedicadas ao primeiro. Com êles estão Denjse Vernac, sua espôsa e o cineasta inglês Lindgren

Figura 2: Denise Vernac, Ernest Lindgren e Alberto Cavalcanti, momentos antes da inauguração da retrospectiva em homenagem a Erich von Stroheim | @ Revista Visão/ DCI Shopping News.

Para a retrospectiva, foram escolhidos 13 filmes que ilustraram os vinte e oito anos de carreira de Stroheim como ator e diretor, 9 mas que infelizmente não foram incorporados integralmente ao acervo da Cinemateca, como ocorreu com os filmes dos 'Grandes Momentos'. Ao desembarcar em São Paulo, Stroheim, com ar solene e austero, declarou seu apreço pela homenagem, a primeira grande retrospectiva de sua obra: "Que posso dizer? A retrospectiva de minha obra cinematográfica, completa 
como vai se realizar, faz com que eu contraia uma dívida de gratidão com o Brasil" (Última Hora 11 fev. 1954).

$\mathrm{Na}$ entrevista oficial que concedeu à imprensa, Stroheim enfatizou a importância da mostra, que permitia reforçar que, na década de 1920, já se fazia cinema realista, tal qual o cinema italiano do pós-guerra (1939-45), quando em Ouro e Maldição seguiu as previsões de Griffith e tentou a cor, apresentando cenas amarelas nos momentos em que aparece o ouro; ou quando aboliu os cenários e trabalhou apenas com três atores profissionais, sendo o restante "gente da rua". Afirmando-se como precursor do neorrealismo italiano, Stroheim investiu violentamente contra o cinema estadunidense e contra os musicais, segundo ele, filmes fáceis que, buscando agradar, preterem a história em relação ao lucro. É a história que faz um bom filme, afinal, "ninguém quer ver pernas nuas e caras bonitas todos os dias, principalmente em tão grande quantidade". Questionado porque não vivia mais em Hollywood, Stroheim respondeu que havia sido tratado pela indústria como um "ferro velho" (Folha da Manhã 12 fev. 1954).

A retrospectiva foi noticiada na primeira página do jornal $O$ Estado de $S$. Paulo, de 14 de fevereiro de 1954, acompanhada da apresentação dos filmes e de uma declaração de princípios do cineasta: "Nunca tirei meu chapéu para as convenções ou para a moda, nem a estendi para receber esmolas. Sempre lhes disse a verdade, tal como a via. Eles gostam ou não, mas de qualquer forma era a verdade tal como a via. Minha recompensa é a consciência limpa". O filme escolhido para a abertura foi Ouro e Maldição, apresentado por Alberto Cavalcanti na sessão de gala (Figura 2). Paulo Emílio justificou a escolha do filme por dois motivos: sua importância tanto para a história do cinema quanto para a cinematografia de Stroheim. De fato, o filme simbolizava a tensão entre arte e comércio, como o próprio diretor fez questão de denunciar lembrando que seu filme havia sido arbitrariamente editado pelos produtores, que haviam transformado sua obra de 8 horas em uma versão comercial de 2 horas (O Estado 14 fev. 1954).

No dia seguinte, a Folha da Manhã enfatizou que "com a homenagem a Von Stroheim, o festival teve um de seus maiores dias" (16 fev. 1954), apesar do atraso da sessão. Rudá de Andrade relatou que, com o atraso, Stroheim relutava em comparecer, por supor o imerecido fracasso e por não acreditar que o cinema estava repleto, à espera de sua presença. Apenas Paulo Emílio, após ir pessoalmente verificar o que se passava no Cine Marrocos, foi capaz de persuadi-lo. Chegando lá, Stroheim encontrou o cinema de mais de mil lugares lotado, a ponto de o público quebrar os vidros e entrar à força, 
ocupando todos os espaços disponíveis. Os que ficaram de fora protestaram, exigindo a realização de uma segunda sessão (Andrade 2004).

Sobre a exibição de Ouro e Maldição, Bazin relatou que compartilhou o cinema com um público leigo e simplesmente disposto, o que para ele demonstrava a vitalidade e a modernidade dessa importante obra do cinema e de seu diretor, que estava entre os três ou quatro grandes nomes da história do cinema, apesar de ter sido malogrado pela crítica cinematográfica à época do lançamento de seus filmes. Consagrado pelo público que chamou de "profano" e verdadeiro, Bazin sustentou que a experiência havia renovado sua apreciação pela obra de Stroheim e comprovado que seu fascínio não havia envelhecido com o desenvolvimento das técnicas cinematográficas (1954).

A Marcha Nupcial foi igualmente um grande sucesso. Paulo Emílio e Stroheim apresentaram uma cópia acompanhada da sonorização original recomposta pela Cinémathèque Française a 4000 pessoas, divididas em duas sessões para atender às manifestações do público. Segundo Bazin, a importância da retrospectiva se sobrepôs às demais manifestações do festival, pois muitos dos filmes exibidos não haviam sido assistidos mesmo pelos frequentadores das cinematecas europeias. Ao contrário da França, onde os filmes antigos como os de Stroheim eram apresentados em cinematecas e cineclubes, o festival brasileiro programou-os em grandes cinemas, com capacidade para 2000 pessoas, o que produziu uma alteração na escala a que os franceses estavam acostumados, em matéria de sessão cinematográfica. 0 festival mostrava que além das "capelas" (cineclubes) "irradiando" cultura cinematográfica "em torno das catedrais" (cinematecas), os franceses não deveriam se esquecer de "rezar a missa no grande altar" (palácios de cinema) (Bazin 1954, 29).

O grande sucesso da retrospectiva Erich von Stroheim foi interpretado por Claude Lefort à luz de uma tensão entre arte e comércio. Segundo ele, os filmes da retrospectiva não haviam perecido com o tempo, continuavam belos ou mesmo melhores. Havia unidade entre forma e fundo, entre a linguagem e os temas, como nas obras de arte. Lefort comparava Stroheim aos grandes autores de literatura: "Há um universo de Stroheim como há um de Proust ou de Faulkner", “denso, problemático, completo”, no qual os pensamentos conduzem sempre a alguns símbolos essenciais e situações que reproduzem os mesmos "elementos trágicos", onde todos eles apresentam uma "visão do fracasso inexorável” dos seres humanos. É nisso que reside o realismo de sua obra (Lefort 1954, 21-24). 
Um realismo poderoso, que havia ampliado o contraste entre o propósito comercial da Seleção Oficial e a qualidade artística dos filmes de Stroheim, tomando-os em oposição como obra proposital dos organizadores do festival. Ao passo que os filmes contemporâneos seguiam a "regra de ouro" do momento, "falar para nada dizer", a retrospectiva de Stroheim realizada pela manhã e às altas horas da noite se afirmou como "uma perfídia" que Eric Johnston ${ }^{10}$ e seus semelhantes não poderiam sequer perceber, mas que "encantou todos os amantes do verdadeiro cinema". Nesse quesito, o festival de São Paulo fez uma "pequena revolução" (Lefort 1954, 15) contrapondo a arte ao comércio para acentuar as disputas entre o cinema europeu e estadunidense.

A escolha dos filmes de Stroheim para "acompanhar" e "minar o festival oficial" não foi apenas feliz, foi "duplamente simbólica", pois não se tratava apenas de filmes que reivindicavam a "verdade", o realismo, como os filmes de Chaplin e Eisenstein, mas de "vítimas do cinema comercial e oficial". O público, não iniciado em sua maioria, como descreveu Bazin (1954), aprendeu que Stroheim era um dos maiores diretores de cinema e teve sua carreira assolapada pelos dirigentes da Goldwyn-Mayer. Embora a compreensão dessas questões não tenha sido absoluta, o relevo conferido à obra de Stroheim se afirmou, para Lefort, como um "antifestival" de grande sucesso (1954 15-17).

Contudo, interpretar a tensão entre a Seleção Oficial e as mostras culturais como propósito da organização do festival nos parece um tanto quanto equivocada, embora tenha sido essa a impressão que se cristalizou em alguns setores da crítica local e estrangeira. Se, no panorama 'Grandes Momentos', cada cinematografia é apresentada em seus momentos decisivos, na 'Retrospectiva Erich von Stroheim' o paradigma estadunidense é tratado como ceifador das experiências artísticas do realizador. Certamente, as declarações do cineasta amplificaram a percepção de que o festival opôs arte e comércio, alocando para o segundo plano a disputa artística e comercial entre o cinema estadunidense e europeu.

À época, a crítica cinematográfica brasileira se reconhecia na seguinte divisão: de um lado, os esteticistas, defensores da superioridade técnica do cinema estadunidense (como Francisco Luíz de Almeida Sales) e do outro,

${ }^{10}$ Presidente da Motion Picture Association of America e chefe da delegação estadunidense no festival. 
os críticos históricos, admiradores do cinema europeu e dos conteúdos sociais que poderiam influir nos destinos humanos (Autran 2003). Acreditando que a existência de uma obra precede sua essência, Paulo Emílio é o maior nome da crítica histórica, o que sem dúvida contribuiu para a escolha dos cineastas homenageados (Stroheim e Gance) e para o grande relevo conferido à história do cinema europeu. Contudo, arte e comércio não são interpretadas em oposição, nem por Paulo Emílio nem pelos restantes representantes da crítica local.

\section{Oposição ao festival?}

Apesar do efeito não intencional, a disparidade qualitativa entre os clássicos da cultura cinematográfica e a Seleção Oficial foi explorada pelos opositores do festival e pelas crônicas que se multiplicaram nos jornais. Sobre a programação, parte da imprensa criticou o excesso de filmes e projeções simultâneas, tidas como "a origem de um fracasso já previsto" (O Jornal 15 fev. 1954). A Vera Cruz e seus artistas, a TV Paulista, o Sindicado dos Exibidores e setores da imprensa paulista e carioca somaram-se ao coro de críticas, por motivos diversos. 0 Sindicato dos Exibidores denunciou o "preço excessivo" pago pelo aluguel do Cine Marrocos, o que justificava a condução de um inquérito sobre os contratos firmados pela comissão executiva do festival. Outro ponto de indignação depositava-se na constante subida do preço de suas entradas, já que o festival havia dobrado o custo dos ingressos (de 10 para 20, chegando a 55 cruzeiros nas sessões de gala) - objeto de protestos por parte do público. A pressão foi tamanha que o festival foi autuado pela COAP - Comissão de Abastecimento e Preços - por crime contra a economia popular (Folha da Tarde 13 fev. 1954).

0 aumento no preço das entradas foi justificado em decorrência da deterioração do orçamento do festival, estabelecido no ano anterior através de um convênio estadual e federal para custear as despesas estimadas em 20 milhões de cruzeiros. À época em que a soma foi estabelecida, 20 cruzeiros valiam o equivalente a 1 dólar; em fevereiro de 1954, porém, a moeda estadunidense foi cotada em 55 cruzeiros, o que se refletiu diretamente tanto na aquisição de passagens aéreas quanto nos custos de bens locais majorados pela inflação. Mesmo diante desse cenário, a imprensa mais sensacionalista veiculou manchetes questionando onde havia ido parar a verba do festival, insinuando o desbarate com o dinheiro público (O Dia 11 fev. 1954), mesmo tendo o jornal $O$ Tempo publicado a relação completa dos custos do evento (3 fev. 1954). 
Ao mesmo tempo, a Vera Cruz, a TV Paulista e artistas brasileiros como Anselmo Duarte, Liana Duval, Cacilda Becker, Marisa Prado, Ilka Soares e Nicete Bruno protagonizaram manifestações de outra ordem. A convergência desses personagens contra o festival se formava numa mistura de ardor patriótico, coragem pessoal e orgulho paulista, voltado para a proteção dos "interesses do cinema nacional". Paralelamente ao festival, foi realizado o Festival Brasileiro de Cinema, com entrada franca no Cine Normandie, pois, segundo os organizadores, o cinema nacional havia sido relegado ao segundo plano (Notícias de Hoje 25 fev. 1954). Já a TV Paulista, em forma de protesto, afirmou que exibiria filmes brasileiros durante 24 horas, numa Maratona pró-Cinema Nacional. 0 objetivo da campanha, segundo Raul Guastini, diretor do canal, era sensibilizar o governo estadual da importância de financiar a finalização do filme Floradas na Serra, da Vera Cruz, integrando-o às festividades do IV Centenário, pois metade do filme estava pronto e se tratava de uma "produção paulista", com um "roteiro paulista", protagonizado por uma "atriz paulista" (O Tempo 17 fev. 1954). ${ }^{11}$ Solicitou-se, para esse fim, $10 \%$ da verba do festival ( 2 milhões de cruzeiros).

A empresa brasileira amargurava uma severa crise, em parte provocada por uma gestão afoita e pouco criteriosa de Franco Zampari, pelo desperdício do sucesso internacional de O Cangaceiro, resultante de um ruinoso acordo comercial com a Columbia Pictures em sua distribuição internacional (Galvão 1981), e pela deterioração do cruzeiro frente ao dólar. Nessas circunstâncias, a Vera Cruz e seus artistas denunciaram nas páginas da imprensa os gastos "excessivos" do festival com as recepções oferecidas no Automóvel Clube e na Chácara Jandaia para, em contraposição, promover a campanha por Floradas na Serra. A protagonista, Cacilda Becker, afirmou, "com indisfarçável revolta", que pediram à comissão do IV Centenário um "auxílio" para que o filme, já em fase final de produção, pudesse participar, acrescentando: "Dois milhões que fossem emprestados e o Brasil estaria condignamente representado na festa, com um filme prenhe de possibilidades de sucesso" (Shopping News 14 fev. 1954). 0 filme viria a ser o canto do cisne da Vera Cruz, demonstrando que a exacerbação de ânimos contra o festival derivava diretamente da crise econômica pela qual passava a indústria cinematográfica brasileira.

${ }^{11}$ Omitia-se, nessa defesa pública dos interesses paulistas, que a mesma produção era dirigida pelo italiano Luciano Salce. 
Diante dessas manifestações, José Gonçalves de Andrade Figueira, secretário-geral do festival, prestou esclarecimentos sobre a solicitação da Vera Cruz. 0 organizador é categórico: a legislação em vigor, estadual e federal, não permitia financiamento de filmes ou empréstimos, ainda mais para entidades privadas. Referiu ainda que o festival não podia ser penalizado pela crise econômica pela qual passava o cinema nacional (Manchete 27 fev. 1954). 0 então crítico Luiz Carlos Bresser Pereira, em sua coluna de 9 de março de 1954, no jornal $O$ Tempo, classificou a campanha do Festival Brasileiro de Cinema como "um ridículo atroz". Com o acirramento dos ânimos, a Vera Cruz não cedeu Sinhá Moça e Caiçara para a II Retrospectiva do Cinema Brasileiro, alegando que as produções não estavam em condições técnicas de serem exibidas - apesar de Sinhá Moça ter sido já projetado em sessão privada para os diretores Henri Cornelius e Mervyn Le Roy, no estúdio da companhia, uma semana e meia antes, como viria a ser apontado pel' $O$ Globo, a 16 de fevereiro de 1954.

A oposição ao festival também foi sustentada por nomes de peso como Alex Viany, que, em entrevista à revista carioca Manchete, publicada a 13 de fevereiro de 1954, declarou que o festival era "nocivo" ao cinema nacional, pois facilitava a invasão dos filmes estrangeiros medíocres ao mercado interno, taxados apenas por peso na alfândega. Essa disparidade impedia o cinema brasileiro de progredir em seu próprio mercado, enquanto lutava para elevar sua qualidade formal. Segundo Viany, os 20 milhões do festival seriam suficientes para fazer ao menos 10 filmes num momento de agonia da indústria local. Enquanto os "grã-fininhos" festejavam os "figurões do cinema estrangeiro" em coquetéis de gala, quem estava lutando pelo cinema brasileiro não tinha "tempo para coquetéis" e nem poderia "vestir-se a rigor", pois estavam "de mangas arregaçadas, tratando de garantir a subsistência" do cinema brasileiro. Dos opositores, Viany é o mais pragmático de todos; sua manifestação se baseia em dados objetivos que apontam para a posição de desvantagem do cinema brasileiro em seu próprio mercado, frente a completa falta de políticas protecionistas e de incentivo, o que revela a maturação da tese que apresentara no I Congresso Paulista de Cinema (1952) e o seu comprometimento com o desenvolvimento da produção e da distribuição dos filmes brasileiros em seu próprio mercado. 


\section{Cultura ou Comércio: um falso dilema}

Como nos indica Autran (2013), na crítica de cinema brasileira da década de 1950, arte e comércio não são tomadas em oposição, mas de modo complementar, como também os entendiam os idealizadores do festival. Mas, esse falso dilema ganhou bastante fôlego na percepção dos cronistas, tal como podemos verificar nos comentários de Daniel Linguanotto à geografia e seu impacto nas práticas sociais do festival, publicados em 27 de Fevereiro de 1954, na Manchete, manifestando aspectos observados por Stringer (2016) no fenômeno dos festivais de cinema.

0 repórter da revista Manchete criticava a escolha da cidade, cuja grande dimensão teria contribuído para a dispersão dos artistas entre as comunidades locais de imigrantes e recepções de 'grã-finos', relegando os contatos comerciais que poderiam ser estabelecidos ao segundo plano. A localização da cidade, situada no altiplano paulista, teria contribuído para transformar o festival em "enfadonho". Linguanotto lamenta que, se realizado na praia, 12 o festival teria rendido capas nas revistas de todo o mundo, mas o "puritanismo (de fachada)" paulista havia impedido que o Brasil desfrutasse dos "belos espetáculos humanos das praias de Cannes, Veneza e Punta del Este". Na "dureza esfumaçada do asfalto" e na "desanimadora garoa paulistana", o festival do Brasil havia selado seu destino: "encerrar-se-á (como começou) melancolicamente como um congresso de filósofos num inverno bostoniano", quando poderia ter ocupado as capas das principais revistas do mundo com fotos das atrizes de biquíni na praia, tal qual os demais festivais litorâneos da Europa. Não sendo organizado em um balneário ou cidade turística, mas em uma metrópole de 3 milhões de habitantes, o festival se afastou de Cannes e Veneza e se aproximou do festival de Berlim - fisionomia geográfica fundamental para o sucesso do "festival de cultura cinematográfica" (Bazin 1954).

Ao lado da oposição à escolha da cidade, o público manifestou frustração com a ausência de astros e estrelas estadunidenses como Rita Hayworth, Jane Russel e Marylin Monroe, revelando sua predileção pelos filmes comerciais estadunidenses frente aos clássicos. Apesar do sucesso de público das mostras históricas, a imprensa foi rápida em anunciar a impopularidade do festival, baseando sua análise em entrevistas a fãs de

\footnotetext{
120 repórter refere-se diretamente ao Guarujá, cidade litorânea do estado, que havia sido sugerida por Jorge Guinle durante o planejamento do evento.
} 
cinema decepcionados com a presença de poucos nomes conhecidos, como Stroheim, Ninón Sevilla, Michel Simon e Mervin Le Roy, como Domingos Lucca Jr. ressaltou na crônica "Os fãs gritam: Impopular o I Festival de Cinema do Brasil", publicada na Folha da Noite, a 17 de fevereiro de 1954.

Atiçando as polêmicas, o jornal $O$ Mundo precisou de apenas três dias para julgar o festival como "passadista e melancólico", no qual as maiores atrações eram astros velhos como o "feio e rotundo" Stroheim, o "velho" Michel Simon e a atriz cubana Ninón Sevilla, cujo "contorno de suas pernas" ainda valia "meia festa" (15 fev. 1954). Os ataques misóginos ainda se prolongaram na publicação de charges que enfatizavam a beleza das brasileiras em relação às estrangeiras: queriam saber onde estavam as vedetas e os astros estadunidenses mais conhecidos do público (Figura 3).

Para o crítico Henrique Pongetti, na edição de 6 de fevereiro de 1954 do jornal $O$ Globo, bastou a relação nominal dos que viriam ao Brasil para decretar o festival como o "Festival da Saudade". Seis dias antes da inauguração, o cronista afirmou que esse era o resultado óbvio da colaboração de críticos, "grã-finos" e dos "diletantes do Clube dos Herméticos, donos do segredo de Orson Welles e Charles Chaplin", que haviam conseguido trazer a São Paulo, com os banquetes que ofereceram em Hollywood e Paris, "uma velharia com um pouco menos do que os 400 anos de São Paulo" que mais pedia "um museu de cera às margens do Ipiranga". No comentário, o ataque aos "diletantes" e "herméticos" se refere diretamente à tradição do Chaplin Club, ${ }^{13}$ reivindicada por Paulo Emílio e pela Cinemateca Brasileira. Nesse âmbito, as posições dos cariocas Henrique Pongetti e Daniel Linguanotto estavam mais focadas em atiçar as polêmicas do que interpretar a relação complexa entre arte e comércio que se processara no festival.

${ }^{13}$ Primeiro cineclube brasileiro (1928-1930) (Xavier 2017). 


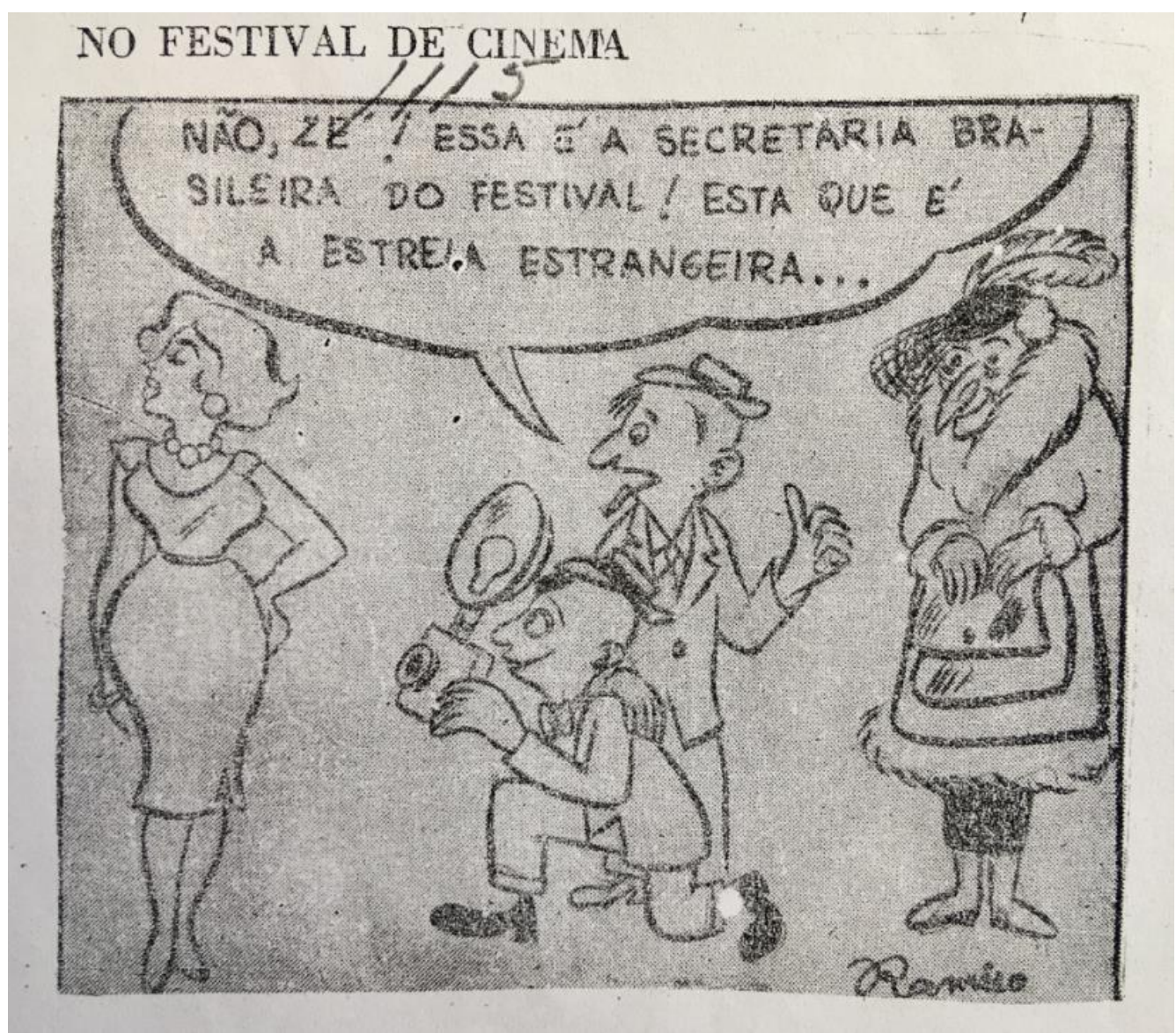

Figura 3: Charge de Ramiro, publicada no jornal Notícias de Hoje 14 fev. 1954 | @ Grupo Notícias de Hoje.

Apenas após a chegada da delegação dos EUA e de artistas mais ou menos conhecidos do público, a 17 de fevereiro, que os ânimos de parte da imprensa brasileira arrefeceram. Bazin interpretou o fato como exemplo da presença dominante do cinema estadunidense na América do Sul, atestado pelas manifestações delirantes que o público havia protagonizado diante do contato com artistas mais ou menos conhecidos $(1954,26)$, esvaziando parte da argumentação da oposição local, insatisfeita com a crise do cinema brasileiro e com o fracasso de suas expectativas comerciais, apesar da tentativa do festival em oferecer ao cinema brasileiro esclarecimentos e soluções de muitos problemas da indústria cinematográfica. Contatos foram firmados, informações compartilhadas, oportunidades de coprodução foram aventadas. 0 diretor estadunidense Mervyn Le Roy assistiu, em sessões privadas, aos últimos filmes da Vera Cruz e declarou que seus planos em filmar no Brasil eram reais. A empresa brasileira também foi procurada pela delegação espanhola, mas nada se efetivou a tempo de salvá-la da falência; a Multifilmes recebeu "propostas quase concretas" de produtores italianos, franceses e alemães, e Eric Johnston 
veio "disposto a encarar o cinema nacional como uma realidade", segundo anunciou o 'Boletim do Festival' da Folha da Tarde, de 20 de fevereiro de 1954. As manifestações do diretor português Leitão de Barros sobre a história da cidade de São Paulo, no jornal $O$ Tempo, de 14 de fevereiro de 1954, e as reações do britânico Henry Cornelius, publicadas no Correio Paulistano de 16 de fevereiro de 1954, fascinado com as paisagens naturais do país, evocaram diretamente o desejo de filmar no Brasil - falas protocolares que, infelizmente, não se efetivaram.

\section{Um festival de cultura cinematográfica: a crítica europeia}

Apontada pelos cronistas como explicação para o fracasso do festival, a oposição entre arte e comércio que o festival teria provocado foi respondida em peso pela crítica europeia, para quem o festival não havia sido um fracasso justamente pela densidade e importância de sua programação cultural. Em entrevistas e textos, os críticos estrangeiros André Bazin, Catherine De la Roche, Francis Koval, Novais Teixeira e Claude Lefort, para além de Langlois, foram unânimes em reconhecer a importância cultural e histórica do evento.

Na Cahiers du Cinéma, Bazin sustentou que a supervalorização das vedetas estadunidenses contradizia suas impressões da cidade "ultramoderna" e da elite intelectual notavelmente francófona que havia conhecido. Em sua percepção, o festival de São Paulo se afirmou moralmente, e não numa vã concorrência com os festivais europeus (1954). Em entrevista, o secretáriogeral J.G.A. Figueira enfatizou que o festival de cinema não era apenas uma festa onde se reuniam vedetas e artistas para exibição de vestidos e biquínis, mas sim um congresso onde cada país procurava apresentar o melhor da sua produção para que todos aproveitassem as lições aprendidas com o intercâmbio cultural. Nas palavras de Figueira, na entrevista "Festival de cinema não é exibição de biquínis", publicada na revista Manchete, de 27 de fevereiro: "quisemos mostrar ao mundo que já passamos à categoria de povo culto e civilizado". Nesse propósito, "convidar moças bonitas para exibir as pernas em nossas praias não era fazer a propaganda do Brasil, conforme nosso desejo".

Em crônica para o Suplemento Especial Cinematográfico do jornal O Estado de S. Paulo, publicada no mesmo dia, o crítico Novais Teixeira corroborou essa posição destacando que não estava entre os propósitos do festival "urdir paraísos infantis abertos aos horizontes limitados de homens sem imaginação". Ao contrário, o festival fora um completo curso de história do 
cinema e marcara um novo capítulo da cultura cinematográfica no Brasil, pois sua importância se equiparava à "extraordinária" II Bienal de artes plásticas de São Paulo. Deveria ser ressaltado ainda que a programação do Cine Marrocos e dez por cento da programação das Jornadas Nacionais equivaleria quantitativamente aos programas dos festivais de Cannes e Veneza, dada sua grande dimensão: 0 festival foi "espetáculo vivo com a incorporação integral do público, o que constituiu a parte mais inesperada e mais apreciável das programações". Segundo o crítico português, "o último milagre de São Paulo foi decerto, o de oferecer ao mundo um de seus festivais de cinema mais importantes, sem ter passado pela fase do aprendizado". Catherine De la Roche, correspondente da BBC e das revistas Everybody e Spectator, teve sua crítica traduzida e republicada pelo jornal Última Hora, de 3 de junho de 1954, na qual compartilhou da opinião de Teixeira: "Dizem às vezes que os festivais cinematográficos são apenas publicidade disfarçada de cultura". Seja como for, acrescenta De la Roche, o festival brasileiro "proporcionou cultura indisfarçada, seu alcance foi sem precedentes e sua publicidade deve-se principalmente aos seus próprios méritos". O próprio Langlois declarou, em entrevista para a televisão que, se o festival de Veneza era uma reunião mundana e Cannes um encontro diplomático, São Paulo se impôs como um fenômeno cultural (Chalmers 2002).

As retrospectivas do Festival foram retomadas no mês de março e se estenderam até dezembro. Não por acaso, Paulo Emílio classificou o festival como a maior oportunidade de formação cultural cinematográfica jamais apresentada na América Latina, embora reservasse consigo a percepção de que o evento não atingiu o aproveitamento desejado, ou ainda, que suas proporções talvez tivessem sido prematuras para o contexto brasileiro. Apesar das incertezas, Paulo Emílio estava seguro que, durante aqueles dez meses, os quadros limitados de cultura cinematográfica existentes em São Paulo viveram experiências decisivas, conforme sustentou no artigo "O cinema na Bienal", publicado em 8 de junho de 1957 em sua coluna do Suplemento Literário d' O Estado de S. Paulo. 


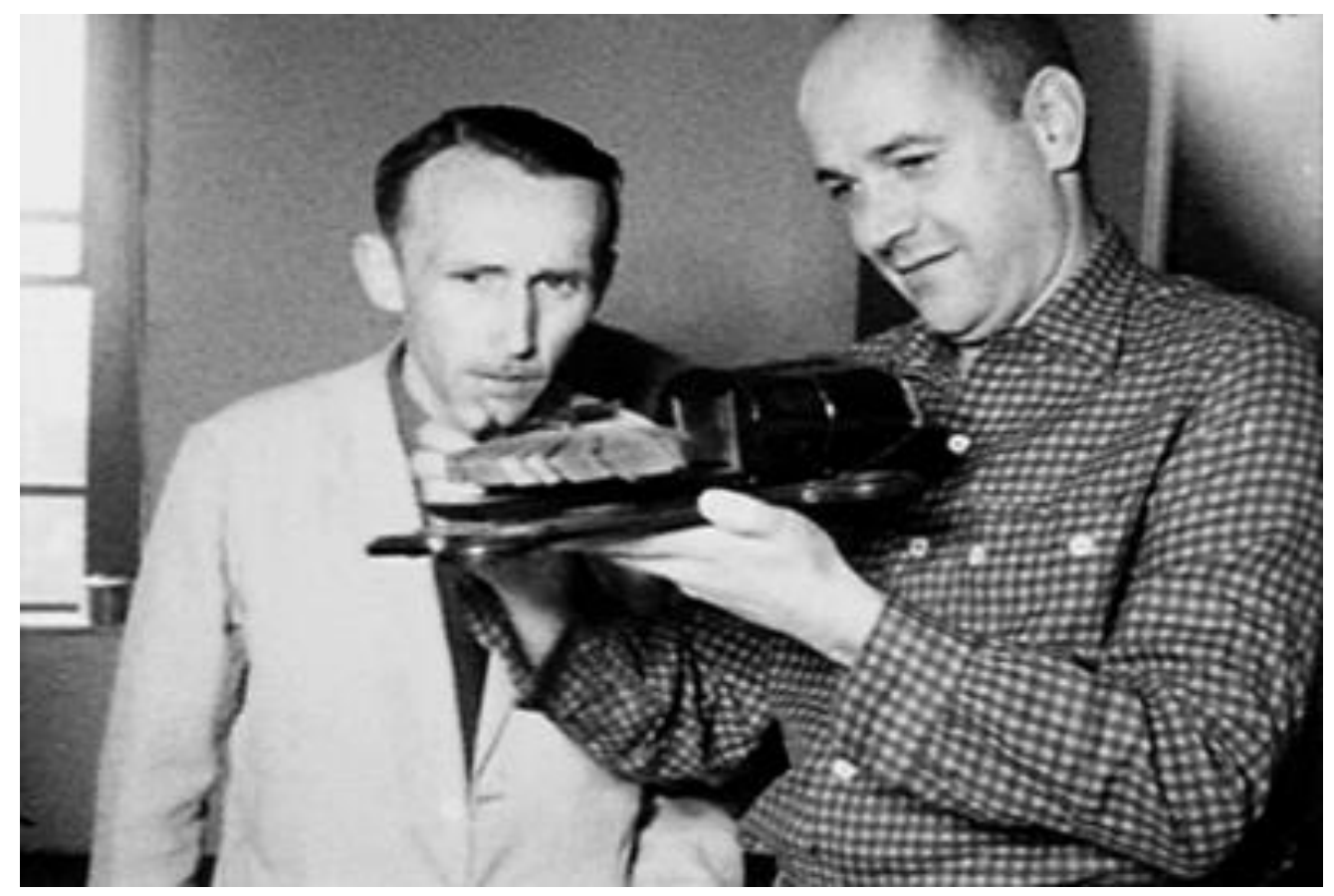

Figura 4: Paulo Emílio apresenta a André Bazin um Kinora Mutoscope em visita à Filmoteca do MAM-SP | (C) Cinemateca Brasileira.

\section{Conclusão}

O fato é que I Festival Internacional de Cinema do Brasil não passou da primeira edição, fracassou em seu objetivo de participar do circuito internacional de festivais de cinema que tomava forma a partir da Europa. Diante das fontes examinadas, acreditamos que o fato de o festival não ter passado da primeira edição não pode ser explicado pela qualidade artística dos filmes exibidos na Seleção Oficial, nem pela oposição entre arte e mercado, comércio e cultura que o festival teria suscitado. Como vimos, essa discussão se dá mais no âmbito da rivalidade artística e econômica entre os cinemas estadunidense e europeu do que propriamente na falsa oposição entre arte e mercado. A resposta poderá estar na complementaridade destas duas valências como objetivo fundamental da iniciativa.

$\mathrm{Na}$ realidade, o festival teve apenas uma edição pelo fato de que foi concebido como parte das festividades do IV Centenário de São Paulo, e não de um plano de maior fôlego delineado entre o governo e os setores produtivos. Acreditamos que, mesmo que a Seleção Oficial tivesse sido um sucesso, dificilmente o festival teria tido uma segunda edição nos anos seguintes - como ocorreu com o Festival de Mar del Plata (Argentina), que, após a primeira edição, realizada um mês após o festival brasileiro, padeceu de uma interrupção de quatro anos. No caso brasileiro, relativo às questões 
propriamente comerciais, o destino do festival acentuou algumas prioridades, como o apoio governamental e legislativo à produção nacional, sem que isso implicasse medidas efetivas para o desenvolvimento substancial da produção, um assunto tratado com maior seriedade pelo poder público apenas a partir da fundação da Embrafilme (1969).

No caso da programação cultural, a aquisição das cópias da mostra 'Grandes Momentos do Cinema' representou um ganho sem precedentes para a realização das atividades culturais da Cinemateca Brasileira, tanto de suas atividades internas como do empréstimo de cópias em $16 \mathrm{~mm}$ para os cineclubes (Correia 2010). 0 festival também agregou experiência à equipe da instituição na organização de mostras e festivais de história do cinema, que se seguiriam, com vários recortes nacionais e temáticos, nomeadamente: os festivais 10 Anos de Filmes sobre Arte (1956), Semana de Cultura Cinematográfica (1959) e o Festival de Cinema Russo-Soviético (1961-1962), realizados, em sua maioria, no âmbito das bienais de arte do MAM-SP. Buscava-se, com as mostras, discutir, na sociedade brasileira, a necessidade de preservação do patrimônio audiovisual, contribuir para formação cultural de realizadores e ressaltar a utilidade pública da instituição, reconhecida oficialmente apenas em 1976, após amargar um incêndio (1957) e enfrentar uma profunda crise a partir do golpe civil-militar de 1964 .

Para o contexto brasileiro, a exibição dos clássicos da cultura cinematográfica nos festivais da Cinemateca foi bastante significativa. Estas exibições abasteceram novas gerações de críticos, cineclubistas e realizadores de lições artísticas experimentadas nos momentos decisivos da história do cinema, com as quais aprimoraram seus juízos e agregaram paradigmas culturais de outras escolas cinematográficas, na busca de uma fisionomia própria. Após quase sete décadas, as lições do festival sobrevivem nas atividades da Cinemateca Brasileira, não obstante as interrupções a que têm sido sujeitas. Há quase um ano, a instituição está fechada, impactando negativamente, cultural e economicamente, a produção de filmes e pesquisas acadêmicas, apesar da mobilização de personalidades e instituições, brasileiras e estrangeiras, que têm pugnado pela sua imediata reabertura. Mais uma vez, vemo-nos confrontados com a dimensão da importância da solidariedade e da diplomacia como instrumentos de defesa da cultura e do mercado cinematográfico nacionais. Foram esses os valores que, há quase 70 anos inspiraram o I Festival Internacional de Cinema do Brasil, e que hoje perseveram nas ações e manifestações dos que resistem à inanição da instituição. 


\section{Referências}

Andrade, Rudá. 2004. "Fragmento de uma festa centenária." Em Festival Internacional de Cinema de 1954, editado por Reinaldo Cardenuto, 47-50. São Paulo: Centro Cultural São Paulo.

Autran, Arthur. 2013. O Pensamento Industrial Cinematográfico Brasileiro. São Paulo: Hucitec Editora.

- 2003. Alex Viany: Crítico e Historiador. São Paulo: Editora Perspectiva.

Bazin, André. 1954. "Un Festival de la Culture Cinematographique." Cahiers du Cinéma 6, 34, Avril 1954: 23-29.

Chalmers, Vera Lúcia. 2002. "Festival Internacional de Cinema." Remate De Males 22 (2), 291-319.

Correia Jr, Fausto Douglas. 2010. A Cinemateca Brasileira: Das Luzes aos Anos de Chumbo. São Paulo: Editora UNESP.

2012. O Cinema como Instituição: A Federação Internacional de Arquivos de Filmes (1948-60). Tese de Doutorado em História, Universidade Estadual Paulista.

De Valck, Marijke, Brendan Kredell, e Skadi Loist (eds). 2016. Film Festivals: History, Theory, Method, Practice. London, New York: Routledge. . 2007. Film Festivals: From European Geopolitics to Global Cinephilia. Amsterdam: Amsterdam University Press.

Elsaesser, Thomas. 2005. European Cinema: Face to Face With Hollywood. Amsterdam: Amsterdam University Press.

Galvão, Maria Rita. 1981. Burguesia e Cinema: O Caso Vera Cruz. Rio de Janeiro: Editora Civilização Brasileira.

Koval, Francis. 1954. "Film Festival in Brazil. Discriminating Audiences in São Paulo." The Tablet, Março 27, 1954, 306-307.

Lefort, Claude. 1954. "L'Antifestival." Alliance: Revista de Cultura FrancoBrasileira, Março 1954, 15-17.

Mendes, Adilson. 2013. Trajetória de Paulo Emílio. São Paulo: Ateliê Editorial.

Ostrowska, Dorota. 2016. "Making film history at the Cannes film festival" Em Film Festivals: History, Theory, Method, Practice, editado por Marijke De Valck, Brendan Kredell, e Skadi Loist, 18-33. Londres, Nova Iorque: Routledge. 
Souza, Carlos Roberto de. 2009. A Cinemateca Brasileira e a Preservação de Filmes no Brasil. Tese de Doutorado em Comunicação, Universidade de São Paulo.

Souza, José Inácio de Melo. 2002. Paulo Emílio no Paraíso. São Paulo: Editora Record.

2005. Congressos, Patriotas e Ilusões e Outros Ensaios de Cinema. São Paulo: Linear B.

Stringer, Julian. 2016. "Film festivals in Asia: Notes on history, geography, and power from a distance," Em Film Festivals: History, Theory, Method, Practice, editado por Marijke De Valck, Brendan Kredell, e Skadi Loist, 34-48. London, New York: Routledge.

Xavier, Ismail. 2017. Sétima Arte: Um Culto Moderno, o Idealismo Estético e o Cinema. São Paulo: Edições Sesc.

\section{Filmografia}

A Marcha Nupcial (The Wedding March) [longa-metragem, arquivo digital] Dir. Erich von Stroheim. Paramount Pictures, EUA, 1928. 113 min.

A Princesa e o Plebeu (Roman Holiday) [longa-metragem, arquivo digital] Dir. William Wyler. Paramount Pictures, EUA, 1953. 118 min.

Amor de Outono (Le blé en herbe) [longa-metragem, arquivo digital] Dir. Claude Autant-Lara. Franco London Films et al., França, 1954. 106 $\min$

Begone Dull Care [curta-metragem, arquivo digital] Dir. Norman MacLaren e Evelyn Lambart. National Film Board, Canadá, 1949. 8 min.

Caiçara [longa-metragem, arquivo digital] Dir. Adolfo Celi et al. Companhia Cinematográfica Vera Cruz S.A., Brasil, 1953. 92 min.

Chamas no Cafezal [longa-metragem, arquivo digital] Dir. José Carlos Burle. Memória Civelli Produções Culturais Ltda.; Multifilmes S.A., Brasil, 1954. $84 \mathrm{~min}$.

Condenados [longa-metragem, arquivo digital] Dir. Manuel Mur Oti. Cervantes Films, Espanha, 1953. 94 min.

Coração que Dança (Das tanzende Herz) [longa-metragem, arquivo digital] Dir. Wolfgang Liebeneiner. Capitol-Film GmbH, Alemanha, 1953.90 $\min$. 
Entre o Mar e o Tendal [curta-metragem, arquivo digital] Dir. Alexandre Robatto Filho. Prefeitura da Cidade de Salvador; Diretoria do Arquivo e Divulgação e Estatística, Brasil, 1953. 22 min.

Esposas Ingênuas (Foolish Wives) [longa-metragem, arquivo digital] Dir. Erich von Stroheim. Jewel Productions, EUA, 1922. $142 \mathrm{~min}$.

Floradas na Serra [longa-metragem, arquivo digital] Dir. Luciano Salce. Companhia Cinematográfica Vera Cruz S.A., Brasil, 1954. 100 min.

Fortunas Escondidas [curta-metragem, arquivo digital] Dir. H.B. Corell. Multifilmes S.A., Brasil, 1954.

Houen Zo! [curta-metragem, arquivo digital] Dir. Herman Van Der Horst. Holanda, 1952. 20 min.

Hulha Branca [curta-metragem, arquivo digital] Dir. Silva Brandão. Filmes Albuquerque, Portugal, 1953. $14 \mathrm{~min}$.

Julieta (Julietta) [longa-metragem, arquivo digital] Dir. Marc Allégret. Indusfilmes et al. França, 1954. 96 min.

Julius César [longa-metragem, arquivo digital] Dir. Joseph L. Mankiewicz. MGM, EUA, 1953. 120 min.

La Loca [longa-metragem, arquivo digital] Dir. Miguel Zacarías. Producciones Zacarías S.A., México, 1952. 91 min.

Música e Lágrimas (The Glenn Miller Story) [longa-metragem, arquivo digital] Dir. Anthony Mann. Universal Pictures, EUA, 1954. 115 min.

Na Senda do Crime [longa-metragem, arquivo digital] Dir. Flamínio Bollini Cerri. Companhia Cinematográfica Vera Cruz S.A., Brasil, 1954. 71 min.

Nada Além das Horas (Rien que les heures) [longa-metragem, arquivo digital] Dir. Alberto Cavalcanti. França, 1926. 45 min.

Napoleão [longa-metragem, arquivo digital] Dir. Abel Gance. Ciné France et al., França, 1927, 222 min.

Noites de Circo (Gycklarnas afton) [longa-metragem, arquivo digital] Dir. Ingmar Bergman. Sandrews, Suécia, 1953. 93min.

O Amor de uma Mulher (L'Amour d'une femme) [longa-metragem, arquivo digital] Dir. Jean Grémillon. Les Productions Cinématographiques (L.P.C.) et al., França, 1953. 104 min.

$O$ Cangaceiro [longa-metragem, arquivo digital] Dir. Lima Barreto. Companhia Cinematográfica Vera Cruz S.A., Brasil, 1953. 105 min. 
O Cerro dos Enforcados [longa-metragem, arquivo digital] Dir. Fernando Garcia. Fundo do Cinema Nacional, Portugal, 1954. 118 min.

O Coração Revelador (The tell-tale heart) [curta-metragem, arquivo digital] Dir. Ted Parmelee. United Productions of America, EUA, 1953. 8 min.

O Curandeiro (Le guérisseur) [longa-metragem, arquivo digital] Dir. Yves Ciampi. Les Films du Cyclope et al., França, 1953. 92 min.

O Gigante de Pedra [longa-metragem, fragmentos] Dir. Walter Hugo Khouri. Cast Cinematográfico Brasileiro Ltda., Brasil, 1954.

O Sol nos Olhos (Il sole negli occhi) [longa-metragem, arquivo digital] Dir. Antonio Pietrangeli. Titanus et al., Itália, 1953. 98 min.

Ouro e Maldição (Greed) [longa-metragem, arquivo digital] Dir. Erich von Stroheim. MGM, EUA, 1924. 140 min.

Pão, Amor e Fantasia (Pane, Amore e Fantasia) [longa-metragem, arquivo digital] Dir. Luigi Comencini. Titanus, Itália, 1953, 93 min.

Puplia al Viento [curta-metragem, arquivo digital] Dir. Enrico Gras e Danilo Trelles. Comisión Nacional de Turismo, Uruguai, 1949. 14 min.

Quick, o Esquilo (Quick, das Eichhörnchen) [curta-metragem, arquivo digital] Dir. Heinz Sielmann. Institut für Film und Bild in Wissenschaft und Unterricht (FWU), Alemanha, 1953. $13 \mathrm{~min}$.

Sinhá Moça [longa-metragem, arquivo digital] Dir. Tom Payne e Oswaldo Sampaio. Companhia Cinematográfica Vera Cruz S.A., Brasil, 1953. $120 \mathrm{~min}$.

The Romance of Transportation in Canada [curta-metragem, arquivo digital] Dir. Colin Low. National Film Board, Canadá, 1952, 12 min.

Turay, Enigma de las Llanuras [curta-metragem, arquivo digital] Dir. Enrico Gras e Antonio Enrico Jiminez. C.U.F.E., Uruguai, 1950.

Vitrais de Arte (Artigianato italiano: vetrate artistiche) [curta-metragem, arquivo digital]. La Settimana Incom, Itália, 1949. 1 min. 


\section{The First International Film Festival of Brazil (1954)}

ABSTRACT The 1st International Film Festival of Brazil (1954) was Brazil's attempt to participate in the international circuit of film festivals that gained momentum in Europe after the Second World War. Conceived as part of the celebrations of the 4th Centenary of the city of São Paulo, the festival was based on the model of the festivals of Cannes, Venice, Brussels (1947) and Knokke Le Zoute (1949). Deepening the lessons of European festivals, the Brazilian event harmonized in its programming samples of commercial focus and cultural retrospectives, but the failure of local commercial expectations and the success of cultural programs crystallized the perception, among part of the critics and chroniclers, that art and the market were arranged in opposite poles, in which commercial exhibitions had been neglected vis-à-vis retrospectives and cultural activities. By historically analyzing the case of the festival, we will see how its commercial failure and uniqueness resulted directly from the economic crisis that hit the country and the local film industry, demonstrating that the opposition between art and commerce actually reflects disputes between US and European cinematographies. We will also see that the vitality of cultural programs was fundamental for the good repercussion the event had in foreign criticism, avoiding the complete failure of the initiative.

KEYWORDS I Festival Internacional de Cinema do Brasil; film culture; film festivals; Paulo Emílio; art and market; film archives.

Recebido a 15-07-2020. Aceite para publicação a 1-12-2020. 